\title{
In vitro Study of the Structure and Adhesive Interface in Direct Restorations with Experimental Nanocomposite Materials and Adhesive Systems
}

\author{
ANCA PORUMB ${ }^{1}$, ADRIAN ALMASI ${ }^{2}$, LIANA TODOR ${ }^{1 *}$, CRISTIAN ADRIAN RATIU ${ }^{1}$, GABRIELA CIAVOI $^{1}$, PAULA CRISTINA TODOR ${ }^{3}$, \\ SERGIU ANDREI TODOR ${ }^{4}$, MADALINA NICOLETA MATEI ${ }^{5}$, CRISTIAN ROMANEC ${ }^{6}$, RUXANDRA ILINCA MATEI ${ }^{1}$ \\ 'University of Oradea, Faculty of Medicine and Pharmacy, 10, 1 Decembrie Sq.,Oradea, Romania \\ 2Private Dental Office Adrian Almasi, Oradea, Romania \\ ${ }^{3}$ Iuliu Hatieganu University of Medicine and Pharmacy Cluj-Napoca, Faculty of Medicine, 36 Eroilor Str. 400129, Cluj Napoca, \\ Romania \\ ${ }^{4}$ Victor Babes University of Medicine and Pharmacy Timisoara, Faculty of Dental Medicine, 2 Eftimie Murgu Sq.,300041, Timisoara, \\ Romania \\ ${ }^{5}$ Dunarea de Jos University of Galati, Medicine and Pharmacy Faculty, Departament of Dentistry, 47 Domneasca Str.,800008, \\ Galati, Romania \\ ${ }^{6}$ Grigore T. Popa University of Medicine and Pharmacy lasi, Faculty of Medicine, 16 Universitatii Str., 700115, lasi, Romania
}

\begin{abstract}
Using nanotechnology to produce composite materials it has been possible to obtain materials with similar or better mechanical properties than previous generation of microhybrids, and with exceptional aesthetics and chandelier due to the particularities of nanomaterials. At the same time, the improvement of adhesive techniques to enamel and dentin allowed the expansion of the area of direct composite restorations with a better prognostic over time.Eight carie-free molars were used and each of them was prepared with two class II cavities, which were filled using the C13 and C20 nanocomposites and the A1 and A2 experimental adhesive systems prepared at the Raluca Ripan Chemistry Research Institute. The teeth were divided into four groups of two teeth each, depending on the adhesive system and the composite material used. Scanning electron microscopy images (SEM) have described the adhesive interface and structure characteristics for the two nanocomposite materials and for the two studied adhesive systems.The studied nanocomposites have a variable number of porosities and air bubbles, with a clinical importance which is yet hard to establish.The experimental adhesives used produce a good interface and infiltration of the smear-layer but have not been visualized inside the dentinal canals. In vitro studies are necessary to evaluate the durability of adhesion in the case of self-etch adhesives in one or two steps.
\end{abstract}

Keywords: nanocomposite, adhesive system, scanning electron microscopy

Composite materials have been constituted, since their implementation in the early 1960s, from an organic matrix with polymerizable resins, reinforcement fillers and silane coupling agents $[1,2]$. The organic matrix is usually composed of one or more dimethacrylic monomers such as Bis-GMA, UDMA and TEGDMA, and the inorganic filler of various types of particles, mainly based on glass, silica or metal oxides [3-5]. The process of improving the properties of composite materials has been continuous, by enhancing the mechanical, physical, aesthetic and biocompatibility properties, meeting the needs of practitioners and aesthetic requirements of patients [6].

With all these improvements, long term studies of lateral restorations show that amalgam has better survival rates than composite restorations, underlining the need to study and better understand the failure mechanisms of composite materials and the measures needed to increase the success rate $[7,8]$.

Using nanotechnology to produce composite materials it has been possible to obtain materials with similar or better mechanical properties than previous generation of microhybrids, and with exceptional aesthetics [6,9-11]. At the same time, the improvement of adhesive techniques to enamel and dentin allowed the expansion of the area of direct composite restorations with a better prognostic over time [12].

The relevance of the adhesion phenomena is important for various clinical specializations like orthopedics [13-15], dentistry $[16,17]$, neurosurgery $[18,19]$, abdominal surgery $[20,21]$, gynecology [22,23], and ophthalmology [24].

\section{Experimental part}

Material and method

The purpose of this study was: structural characterization of two experimental nanocomposites (C13 and C20 produced by Raluca Ripan Chemistry Research Institute) and evaluation of the marginal adaptation and adhesive interface achieved with two experimental adhesive systems (A1 and A2).

Investigation was done using scanning electronic microscopy (SEM).

\begin{tabular}{|c|c|c|}
\hline $\begin{array}{c}\text { Composite materials/ } \\
\text { producer }\end{array}$ & The organic phase & Inorganic fillers \\
\hline C13 (RRCRI) & Bis-GMA, TEGMA & $\begin{array}{c}\text { Barium glass, quartz, colloidal silica, zinc glass } \\
\text { with zinc and calcium oxides }\end{array}$ \\
\hline C20 (RRCRI) & Bis-GMA, TEGMA & $\begin{array}{c}\text { Glass with strontium and zirconium oxides, } \\
\text { quartz, colloidal silica, hydroxyapatite with } \\
\text { zirconium oxide }\end{array}$ \\
\hline
\end{tabular}

Table 1

COMPOSITION AND TYPE OF NANOCOMPOSITE MATERIALSUSED 


\begin{tabular}{|c|c|c|c|}
\hline $\begin{array}{l}\text { Adhesive system/ } \\
\text { producer }\end{array}$ & Composition & Class/Stages of application & \\
\hline $\begin{array}{l}\text { Adhesive A1 } \\
\text { (RRCRI) }\end{array}$ & $\begin{array}{l}\text { Self-etched Primer: Acid Monomer, HEMA, Ethyl } \\
\text { Alcohol, Water, Camphorochinone, ethyl-4- } \\
\text { dimatilaminobenzoat } \\
\text { Adhesive: acid monomer, Bis-GMA, TEGDMA, HEMA, } \\
\text { camphorochinone, dimethylaminoethyl methacrylate } \\
\text { Inorganic filler: } 15 \% \mathrm{pH}=2.5\end{array}$ & $\begin{array}{l}\text { Self-etching and adhesive Primer two } \\
\text { stages (generation VI) }\end{array}$ & $\begin{array}{c}\text { Table } 2 \\
\text { COMPOSITION } \\
\text { AND TYPE OF } \\
\text { ADHESIVE SYSTEM } \\
\text { USED }\end{array}$ \\
\hline $\begin{array}{l}\text { Adhesive A2 } \\
\text { (RRCRI) }\end{array}$ & $\begin{array}{l}\text { Acid monomer, Bis-GMA, TEGDMA, HEMA, Ethyl } \\
\text { alcohol, Camphorochinone, Ethyl-4- } \\
\text { dimethylaminobenzoate } \\
\text { Inorganic filler: } 10 \% \mathrm{pH}=2\end{array}$ & $\begin{array}{l}\text { Self-etching adhesive in one stage } \\
\text { (generation VII) }\end{array}$ & \\
\hline
\end{tabular}

The composition of the nanocomposite materials used is described in table 1, and that of the adhesive systems in the table 2.

Eight recently extracted wisdom teeth were used. Immediately after extraction, the molars were cleaned ultrasonically and then manually on the root surface, disinfected for $3 \mathrm{~min}$ in $2.5 \%$ sodium hypochlorite solution, rinsed with running water and then stored in artificial saliva (Artisial $₫ /$ Biocodex, France) at room temperature until use (fig.1).

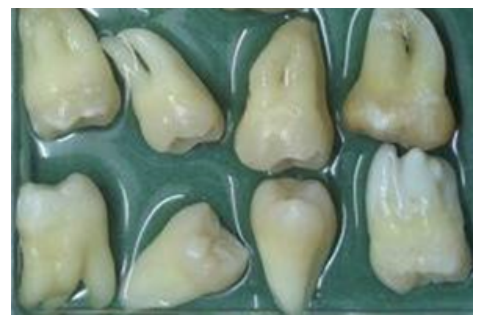

Fig. 1. Extracted

wisdom teeth used in the study

The teeth were divided into four groups of two teeth each, depending on the adhesive system and the composite material used. For ease of handling, the teeth have been fixed in addition sillicone (fig. 2a).
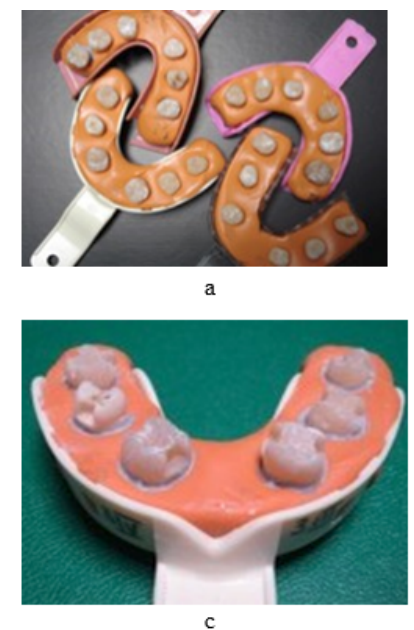

Fig. 2. Stages of preparation of proximal-occlusal cavities on extracted teeth: $a=$ teeth fixed in sillicone, $b=$ preparation of cavities, $c=$ prepared cavities, $d=$ close-up of the cavity preparation process

For each particular molar, two second class cavities (proximo-occlusal) with the following dimensions were prepared: vestibular-oral width 3-4 mm, depth of $2 \mathrm{~mm}$, occlusal-cervical width 4-5 $\mathrm{mm}$, gingival threshold placed at $1-2 \mathrm{~mm}$ coronary amylo-dentinal limit. Vertical cavity walls were prepared in parallel (fig. $2 b, c, d$ ). The contours and internal angles of the cavities were rounded, with no bevel or occlusal extension cavities.
After preparation, the toilets of the cavities were made with physiological saline and restoration was carried out by applying the adhesive system corresponding to the group and then applying the composite material.

The way of combining the adhesive systems and the nanocomposite materials for each group is described in table 3.

Table 3

DISTRIBUTION OF USE OF NANOCOMPOSITES AND ADHESIVE SYSTEMS FOR EACH GROUPFIGURE 6: SEM IMAGES FOR G1 IN DIFFERENT AREAS AND DIFFERENT MAGNIFICATIONS where: A-layer adhesive, C-composite, D-dentine, S-enamel.

\begin{tabular}{|l|c|c|}
\hline Teeth group (n=2) & $\begin{array}{c}\text { Composite } \\
\text { Material }\end{array}$ & $\begin{array}{c}\text { Adhesive } \\
\text { system }\end{array}$ \\
\hline Group 1 & $\mathrm{C} 13$ & $\mathrm{~A} 2$ \\
\hline Group 2 & $\mathrm{C} 13$ & $\mathrm{~A} 1$ \\
\hline Group 3 & $\mathrm{C} 20$ & $\mathrm{~A} 2$ \\
\hline Group 4 & $\mathrm{C} 20$ & $\mathrm{~A} 1$ \\
\hline
\end{tabular}

The application of the adhesive systems was performed in a separate sequence for each of the 16 cavities being taken into operation.

\section{Application protocol of the Al adhesive system}

This two-component adhesive system consists of a selfetching primer as the first layer, followed by the application of the adhesive itself (generation VI). After a light drying process, the primer was applied concomitantly to enamel and dentin by means of an applicator, by light brushing, for $15 \mathrm{~s}$. After drying with air spray for $5 \mathrm{~s}$, the adhesive was applied, also by light brushing for $15 \mathrm{~s}$, followed by drying for $5 \mathrm{~s}$ and curing for $20 \mathrm{~s}$ (Translux Energy $®$ / HeraeusKulzer lamp).

Application protocol of the A2 adhesive system. Adhesive $A 2$ is part of the self-etch monocomponent adhesive systems (VIlth generation). Prior to application, the cavities were gently dried. The adhesive bottle was mixed vigorously for 5-10 s, then with an applicator it was applied by brush over the entire surface of the cavity (fig. 3). After waiting for 15-20 s, the excess adhesive was removed with a strong air spray, perpendicular to the cavity walls, for $5 \mathrm{~s}$. The adhesive was then photopolymerized for 20 s with the Translux Energy ${ }^{\circledR}$ lamp (Heraeus-Kulzer).

After application of the adhesive systems, direct restorations were achieved by the layering and polymerization of each composite material. The application of the first layer of composite material was performed in the form of a triangular prism, in the parapulpal area of the 


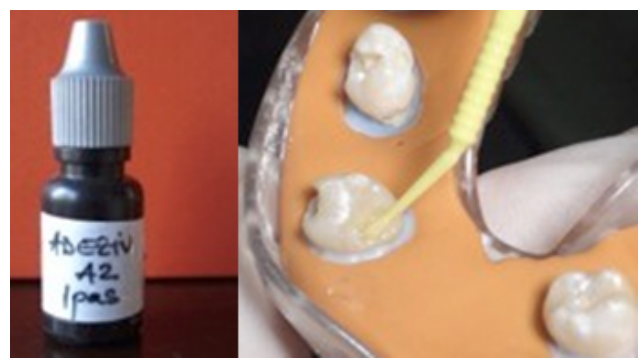

Fig. 3. Presentation and application of self-etching A2 singlecomponent adhesives

gingival wall (fig. 4). The subsequentlayers were overlayed in a centrifugal direction, until the cavities were completely closed.

The thickness of the material was $1.5 \mathrm{~mm}$ and the polymerization time was 40 s due to their increased opacity (fig. 4).

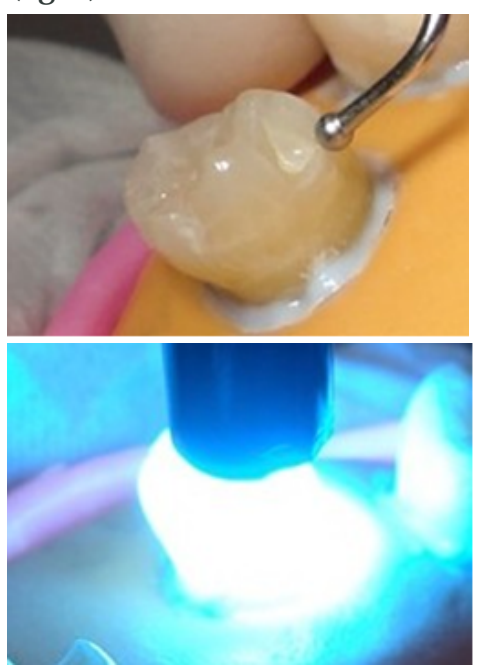

Fig. 4. Stage of layering and polymerization of composite material in the cavity

After the complete reconstruction of the coronary morphology, the final outline was made with eyed diamond cutters and fine and extra-fine flame (e.g. 859-531886, 859531884, 368-532814 / DFS Diamon, Riedenburg, Germany). Polishing started with multi-bolt tungsten carbide cutters (500 314166071014,500314257072018 Acurata ${ }^{\circledR}$ / G + K Manhardt dental, Thurmansbang, Germany) under abundant cooling. Polishing of occlusal surfaces was accomplished by cup-shaped or conical cups of Occlubrush (Kerr, Orange, CA, USA) silicone brushes. The final polish was obtained with the two wicks mounted on the Hi-Luster system (Kerr, Orange, CA, USA): Gloss Plus Polishers, incorporating aluminum oxide particles, and finally HiLuster Plus Dia Polishers containing diamond particles.

The teeth were kept in artificial saliva (Artisial $®$ / Biocodex, France) at room temperature for seven, days then incorporated in transparent autopolymer acrylic resin (Duracryl ${ }^{\circledR} /$ Spofa Dental, Kerr Corp.) and cut in a mesiodistal way by means of a diamond disc microtome (Isomet 1000/Buehler Ltd, USA), at low speed under continuous water jet cooling (fig. 5).

$1.5 \mathrm{~mm}$ thick specimens were obtained, which were cleaned in an ultrasonic tank (Emmi 20®/EMAG

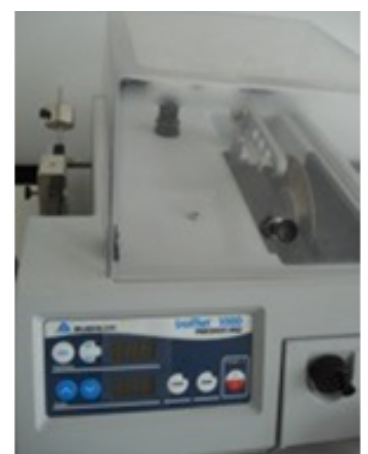

Fig. 5. Isomet 1000 Microtome

Technologies, Germany) in distilled water for three minutes to remove residuals generated by sectioning $[25,26]$.

Specimens were analyzed by scanning electronic microscopy. We have evaluated: the structure of experimental composite materials; the influence of the two adhesive systems used on the adhesive interface; the integrity and continuity of the interfaces between the toothadhesive and the adhesive-composite material respectively.

\section{Results and discussions}

Scanning electron microscopy images have described the adhesive interface and structure characteristics for the studied experimental nanocomposite materials and adhesive systems. Initially, smaller magnifications (40100x) were generally used for overall assessment of the restorations and adhesive interface, then 200-1000x magnification for composite material analysis, and 1000$1500 x$ for the study of the hybrid layer.

In the case of group 1 samples, a continuous interface between the composite-adhesive-dental hard tissue was observed with a continuous and variable thickness adhesive layer that infiltrated the smear-layer (fig. 6a,b,c). In some situations fractures of the composite were observed in the immediate vicinity of the adhesive layer or partial detachment of the adhesive on the dentinal surface (fig. 6b).

The structure of the $\mathrm{C} 13$ nanocomposite material showed a homogeneous hybrid appearance, with the appearance of two irregularly shaped, lightcolored particles of varying diameters betw een 1 and $200 \mu \mathrm{m}$, dark in color, with rounded or oval shape and diameter between 20$40 \mu \mathrm{m}$. On some samples there were visible inclusions of air between 20 and $300 \mu \mathrm{m}$ (fig. 6a,b,c).

In the case of group 2 specimens, the adhesive layer was thin and homogeneous, and the interface was continuous at both the adhesive-adhesive level and the adhesive-dentine level, enamel-adhesive (fig. 7a,b,c). In a small number of cases isolated dehiscences were present at the adhesive-composite interface, the adhesive layer remaining attached to the dentin (fig. 7c). The structure of the composite material was identical to that in Group 1.

The SEM images of group 3 showed a continuous adhesive interface, a thin layer of adhesive of inconsistent thickness, that infiltrated the smear-layer, butno infiltrations could be detected in the depth of dentinal canals (fig. $8 a, b, c)$. In some cases fractures of the composite material

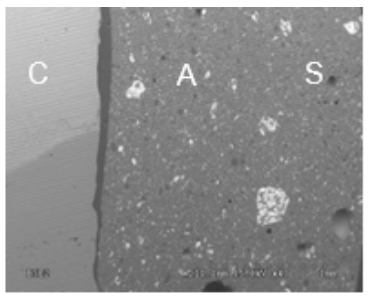

a

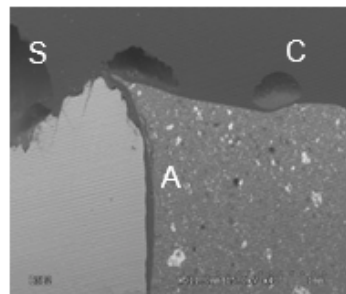

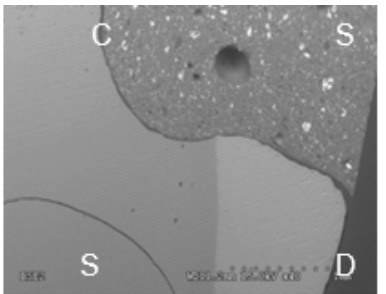

Fig. 6. SEM images for $\mathrm{Gl}$ in different areas and different magnifications,

where: A-layer adhesive, C-composite, D-dentine, S-enamel. 

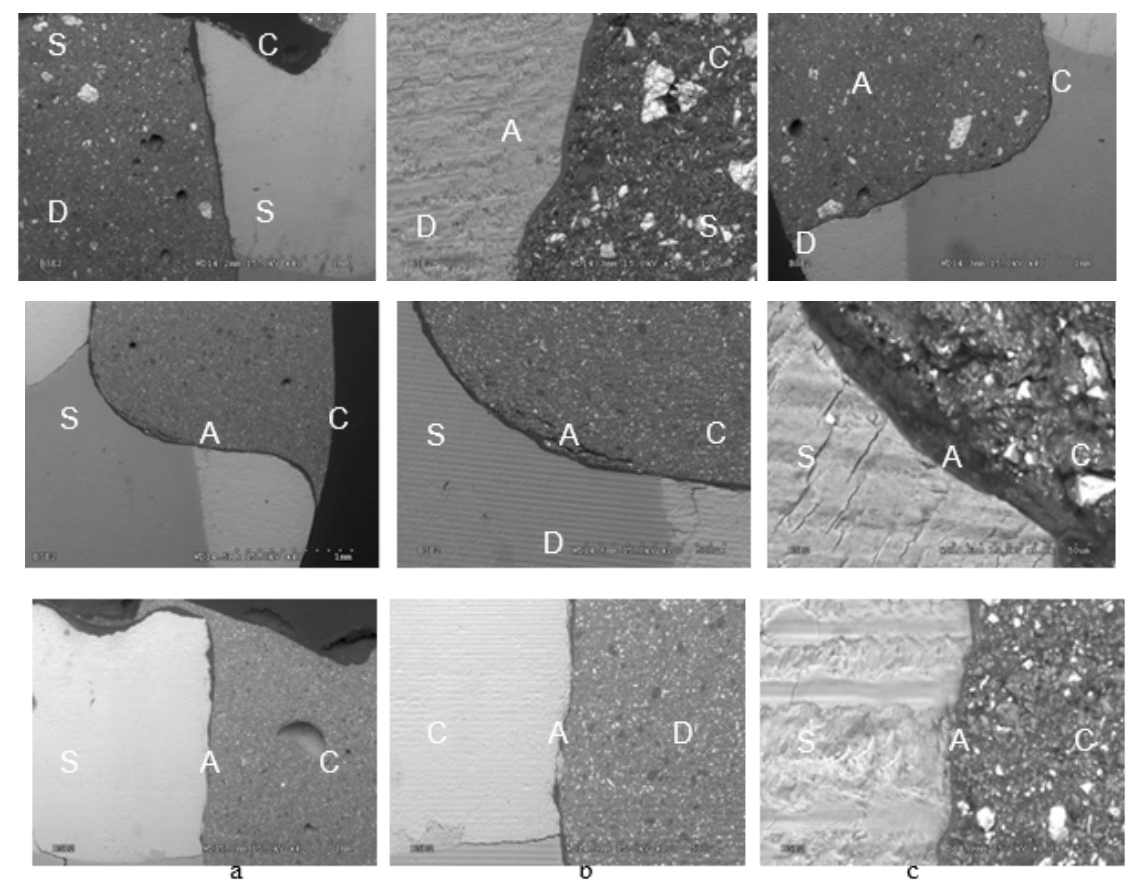

Fig.7. SEM images for G2 in different areas and different magnifications,

where: A-layer adhesive, C-composite, D-dentin, S-enamel

Fig. 8. SEM images for G3 in different areas and different magnifications,

where: A-layer adhesive, C-composite, D-dentin, S-enamel

Fig. 9. SEM images for $\mathrm{G} 4$ in different areas and different magnifications,

where: A-layer adhesive, C-composite, D-dentin, S-enamel were observed in the immediate vicinity of the adhesive layer (fig. 8a, b).

The structure of the C20 nanocomposite material was homogeneous, uniform, with light, irregularly shaped, rounded-edge particles with dimensions between 1 and $15 \mu \mathrm{m}$; light gray particles of irregular shape and diameters up to $10 \mu \mathrm{m}$, as well as dark, round or oval particles with diameters between $10-40 \mu \mathrm{m}$. They were visible on some samples and air inclusions with a diameter between 20 and $300 \mu \mathrm{m}$ (fig. 8a,b,c).

Group 4 microscopic images showed a good adhesive interface with a continuous adhesive layer of non-uniform thickness (fig. 9a,b,c). In some cases fractures of the composite material in the vicinity of the adhesive layer have been observed. The adhesive infiltrated the smearlayer but was not observed inside the dentinal canal.

The structure of nanocomposite material was identical to that of group 3.

Scanning electron microscopy investigation of experimental composites shows compact structures with relatively homogeneous texture and crystalline traces in a predominantly amorphous phase, with the majority of the rounded and well incorporated particles in the organic matrix. These characteristics, as well as the broad particle size distribution, enable the composite material to achieve a good particle arrangement in the monomer mixture and a high degree of bulking, the amount of filler varying between $75-80 \%$ by weight.

The SEM images of the C13 nanocomposite material (figs. 6 and 7) show both light colored, irregularly shaped, sharp-edged particles with diameters between 1 and 200 $\mu \mathrm{m}$ and dark colored particles with rounded or oval shape and diameter Between 20-40 $\mu \mathrm{m}$, distributed homogeneously. This aspect can be explained by the higher presence of barium glass particles in the composition of the material which are of good radiopacity, easy to polish and resistant to wear, have refractive indices similar to the organic matrix but are softer, more soluble and Hard to attach organic matrices than other types of filler [27]. The overall picture seems to be characteristic of a macro-hybrid composite $[27,28]$.

The appearance of the $\mathrm{C} 20$ nanocomposite material (fig. 8 and 9) shows a homogeneous and compact mixture of three types of particles: light, irregularly shaped, rounded margins of between 1 and $15 \mu \mathrm{m}$ in size; Light-gray particles of

Irregular shape and with diameters up to $10 \mu \mathrm{m}$, as well as dark, round or oval particles with diameters between 10-40 $\mu \mathrm{m}$. These correspond to the glass composition with strontium and zirconium oxides, quart, colloidal silica, hydroxyapatite with zirconium oxide, and this composite. The average particle size is much smaller than in $\mathrm{C} 13$, being characteristic of composite material with mid-fill [28].

The continuity of the interface at the adhesive-composite junction and the adhesive-dental tissue also advocates for good maneuverability of these materials and supports a lower polymerization contraction by the increased percentage of filler [21,22]. However, most specimens in $\mathrm{C} 13$ and $\mathrm{C} 20$ showed air inclusions up to $100 \mu \mathrm{m}$ in diameter.

Tw o-step self-etching systems (Adhesive Al) and a onestep self-etching adhesives (Adhesive A2) have been used in the present study. The simplification in the clinical application procedure results in a decrease in adhesive efficacy. Two-step self-etching adhesives are the closest to the gold standard in terms of durability of adhesion, with the added benefit of ease of handling and less sensitive techniques [29].

The two-step self-etching Al adhesive produced a continuous, with a non-uniform thickness adhesive layer with smear-layer infiltration butwithoutvisualization inside the dentinal canals. The $\mathrm{pH}$ of 2.5 places this adhesive in the class of two-step selfetching systems with moderate acidity, able to get closer to the gold standard, producing in-vitro durable adhesion [29-31]. In the present study, adhesive Al showed good adhesion to the interface with dentin and enamel, with only a few situations where the composite layer at the adhesive interface showed cracks, possibly due to polymerization shrinkage. Lack of visualization of the adhesive inside canaliculi can be due to up to 1500x used, lack of acid demineralization of samples, or a very high viscosity of this adhesive, possibly induced by the high percentage of inorganic filler ( $15 \%$ by mass) leads to decreased wetting and intracanalicular infiltration [32].

Adhesive $A 2$ is a self-etching adhesive in one step, with a moderate $\mathrm{pH}$ of 2 . The adhesive interface observed in the present study was continuous, with uneven thickness, smear-layer infiltration but no intracanalicular 
prolongations. Also, this adhesive has produced the most dehiscences, particularly through fractures of the composite material in the immediate vicinity, or, in rare cases, by tearing off the dentin surface. The less sealant interface may be due to the difference in the composition of the acid monomers and the solvent (ethanol in case of A2) $[29,31,33]$. The non-uniform adhesive layer may be generated by the increased consistency of the adhesive due to the presence of the inorganic filler ( $10 \%$ by mass) [34-57].

\section{Conclussions}

The present study highlighted the scanning electron microscopy characterization of experimental dental composite materials and adhesive systems used for restoration in dentistry. The C13 experimental composite exhibits structural homogeneity and a larger number of particles with dimensions between 1-200 $\mu \mathrm{m}$, possibly due to the barium glass composition. The C2O composite has a homogeneous structure with smaller filler particles than C13 and more uniformly distributed. Visualization of nanoparticles is not possible at the SEM magnifications used in this study. Studied nanocomposites have a variable number of porosities and air bubbles, with a difficultclinical relevance.

Adhesive systems of various generations used produce a continuous interface and good marginal adaptation in most cases. Experimental adhesives used produce a good interface and infiltration of smear-layer but have not been visualized inside dentinal canals. Two step self-etching moderate acidity (A1) appear to produce a more continuous and homogeneous interface than those in one step (A2).

The one step self-etching adhesive, $A 2$, exhibits the most dehiscences at the interface with the composite material and the dental structures. In vivo studies are necessary to evaluate the durability of adhesion in the case of self-etch adhesives in one or two steps.

\section{References}

1.NICOLA C, BORZEA D, SECELEANU R., Materiale utilizate în protetica dentarã, Cluj-Napoca: Casa Cartii de Stiinta; 2003: pg. 255 2.FERRACANE J.L., Oral Biol Med 1995;6: pg. 302-318.

3.BOWEN R.L., J Am Dent Assoc 1963; 66: pg.57-64.

4.MOSZNER R., SALZ U., Polymers for Dental and Orthopedic Applications, Boca Raton: CRC Press; 2007. p. 14-67

5.DRUMMOND J.L., J Dent Res 2008; 87(8):710-719

6.TERRY D.A., Applications of nanotechnology. PPAD 2004;16(3):220222.

7.BERNARDO M., LUISH., MARTIN M.D., LEROUX B.G., RUE T., LEITAO J., et al., J Am Dent Assoc 2007; 138:775-783.

8.SONCINI J A, MASEREJIAN N.N., TRACHTENBERG F., TAVARES M., HAYES C., J Am Dent Assoc 2007; 138: pg. 763-772.

9.SAUNDERS S.A., Clinical, Cosmetic and Investigational Dentistry 2009; 1: pg. 47-61

10.BEUN S., GLORIEUX T., DEVAUX J., VREVEN J., LELOUP G., Dent Mater. 2007;23(1): pg 51-59.

11.PALANIAPPAN S., BHARADWAJ D., MATTAR D.L., PEUMANS M., VAN MEERBEEK B., LAMBRECHTS P., Dent Mater 2009;25: pg. 1302-1314 12.ROBERSON T.M., HEYMANN H.O., RITTER A.V., Art\&Science of Operative Dentistry, 4th edition New York: Mosby Inc; 2002, pg.473500

13.ANTONIAC I., NEGRUSOIU M., MARDARE M.,et al., Medicine. 96(19):e6687, 2017

14.GRECU, D., ANTONIAC, I., TRANTE, O., et al., Mat. Plast., 53, no.4, 2016, p.776-780.

15.BENEA, H., LATTANZI ,W., et al., Rev. Chim. (Bucharest), 69, no.2, 2018, p. 515-520.
16.RAU J.V., ANTONIAC I., et al., Materials Science and Engineering C, 64, 2016, p. 362-369.

17.BITA, I., STAN G., NICULESCU, M., CIUCA, I., VASILE, E., ANTONIAC, I., J Adhes Sci Technol., 30(18), 2016, p. 1968-1983.

18.CAVALU, S., KAMEL, E., LASLO, V., et al., Rev. Chim (Bucharest), 68, no.12, 2017, p.2963-2966.

19.VOINESCU, D.C., MOHAN, A.G., MARINESCU, A.A., CIUREA, A.V., Romanian Journal of Morphology and Embriology, 58(1), 2017, p.297300.

20.PARIZA, G., MAVRODIN, C.I., ANTONIAC, I., Mat. Plast., 52, no. 4, 2015, p.484-486.

21.EARAR, K., GRADINARU, S., PARIZA, G. et al., Rev. Chim. (Bucharest), 68, no.8, 2017, p. 1868-1873.

22.CIRSTOIU, M., CIRSTOIU, C., ANTONIAC, I., MUNTEANU, O., Mat. Plast., 52, no.2, 2015, p.258-262

23.BRATILA E., COMANDASU D., MILEA C. et al., J Adhes Sci Technol., 31(18), 2017, p.2028-2043.

24.ANTONIAC I., BURCEA M., IONESCU R.D., BALTA F., Mat. Plast., 52, no.1, 2015, p.109-112.

25.AGUIAR F.H.B., BRACEIRO A.T.B., AMBROSANO G.M.B., LOVADINO J.R., Dent. Mater. 2005;21:pg. 1098-103

26.VAN MEERBEEK B., INOKOSHI S., BRAEM M., LAMBRECHTS P., VANHERLE G., J Dent Res 1992; 71;pg. 1530-1540

27.ALBERS H.F., Tooth-colored restoratives. Principles and techniques. 9th edition Hamilton: BC Decker Inc;2002. p 57-67, 81110, pg.111-125

28.BAYNE S., THOMPSON J .Y., TAYLOR D.F., Art\&Science of Operative Dentistry, 4th edition New York: Mosby Inc; 2002. pg.135-234

29.DE MUNCK J., VAN LANDUYT K., PEUMANS M., POITEVIN A., LAMBRECHTS P., BRAEM M., et al., J Dent Res. 2005;84: pg. 118-32.

30.DE MUNCK J., VAN MEERBEEK B., YOSHIDA Y., INOUE S., VARGAS M., SUZUKI K., et al., J Dent Res 2003;82:pg. 136-140.

31.PEUMANS M., KANUMILI P., DE MUNCK J., VAN LANDUYT K., LAMBRECHTS P., VAN MEERBEECK B., Dent Materi 2005;21: pg. 864881

32.MACARI S., GONCALVES M., NONAKA T., Braz DentJ 2002; 13(1):pg. 33-38

33.VAN LANDUYT K.L., SNAUWAERT J., DE MUNCK J .,, PEUMANS M., YOSHIDA Y., POITEVIN A., COUTINHO E., SUZUKI K., LAMBRECHTS P, VAN MEERBEECK B., Dental Adhesives Biomaterials 2007;28(26): pg. 3757-3785

34.GRADINARU, I. , IGNAT ,L., DASCALU, C.G., SOROAGA, L.V., ANTOHE,M.E., Rev. Chim. (Bucharest), 69, no. 2,2018, p.328-331

35.SOLOMON,S,URSARESCU,I., MARTU,A., et.al., Rev. Chim. (Bucharest), 66, no.8, 2015,p.1166-1168

36.SARBU,LG;LUNGU,N.C,FORNA,N.C.,et.al., Rev. Chim. (Bucharest), 64, no.12, 2013,p.1404-1407

37.COSTAN,A.DIMA,A.,IONITA,I et al, Optoelectrinics and advanced materials-rapid communications,5(1-2),2011, p.92-95

38.ZEGAN G., DASCALU CG, MAVRU R.B., Medical Surgical J ournal, 119(4),2015, pg.1153-1160

39.ANTOHE, M.E., DASCALU, C.,SAVIN, C., FORNA,N.C., BALAN, A., Mat.Plast., 53, no. 4, 2016, pg. 767-770

40.TANCULESCU, O., DOLOCA, A., VIERIU,R.M et al., Rev. Chim. (Bucharest), 67, no.1, 2016,p.96-102

41.MATEI,M.N., EARAR, K., TRINCA,L.C., Rev. Chim. (Bucharest), 67, no.4,2016, pg.800-807

42.MARECI, D., EARAR, K., ZETU, I., et al., Mat.Plast., 52, no.2,2015, pg.150-153

43.ZEGAN, G, ANISTOROAIE, D., GOLOVCENCU , L., et al. Rev. Chim. (Bucharest), 68, no.9,2017, p.2052-2054

44. ANTOHE ME, FORNA AGOP D., DASCALU CG, Rev.Chim. (Bucharest), 69, no.2, 2018 p.521-524

45.POPESCU E, AGOP FORNA D, EARAR, K, FORNA NC, Mat.Plast., 54, no.2, 2017, p. 390-392

46.CHECHERITA, L., BELDIMAN, M.A., STAMATIN ,O., et al., Rev. Chim. (Bucharest), 64, no.8, 2013, p.864-867 
47. ZEGAN,G.,CARAUSU E., M, GOLOVCENCU,L., et al. Rev. Chim. (Bucharest), 68, no.2, 2017, p.2929-2931

48. .JUMANCA,D., GALUSCAN,A.,PODARIU,A.C., et al., Rev. Chim. (Bucharest), 65, no.12,2014, p. 1473-1476

49.ASAFTEI,I.V., SANDU,I.G., BIRSA,L.M., etal., Rev. Chim. (Bucharest), 66, no.3, 2015

50.LUNGU,M.,ROMILA, A., NECHITA,A., et.al., ACTA MEDICA MEDITERRANEA; 33(3), 2017, pg.369-376

51. GRIGORIU,R., CALIN,A.M., ARBUNE,M., et.al., Rev. Chim. (Bucharest), 67, no.2, 2016, p.366-371

52.CALIN, A.D., ,PROCEEDINGS OF $201618^{\text {TH }}$ INTERNATIONAL SYMPOSIUM ON SYMBOLIC AND NUMERIC ALGORITHMS FOR SCIENTIFIC COMPUTING(SYNASC), 2016, PG.264-261
53. COSTEA,C.F., TURLIUC,M.D., DIMITRIU, G., et al., Romanian J ournal of Morphology and embryology,58(3), 2017, pg.739-747 54. CIOATA, R.,BALAN,A., ANTOHE,M.E.,SAVIN,C., IGNAT,G., BASNO,A., Mat.Plast., 53 , no.1, 2016, p.147-149

55..SCUTARIU,M.M., SALAMASTRAKIS,I., STAN,C.I., et al, Romanian Journal of morphology and embryology, 57(3), 2016, pg. 1057-1061 56. OGODESCU,A.S., MORVAY, A.A, BALAN, A., Mat.Plast., 54, no.1, 2017,p.116-118

57. PETCU, A., SAVIN, C., BALAN, A., International J ournal of Medical Dentistry, 21(1), 2017,pg.49-51

Manuscript received: 21.08 .2018 